\title{
THE BETCHWORTH PORTRAITS: MEMBERS OF THE FAMILY OF WILLIAM HARVEY
}

\author{
by
}

\section{ALEX SAKULA*}

\section{SUMMARY}

THE IMMORTAL William Harvey, discoverer of the circulation of the blood, left no progeny, but he had six brothers, and through them (and especially his brother Eliab), the Harvey line was continued for many generations, until with the death in 1830 of Eliab's great-great-great grandson, Admiral Sir Eliab Harvey, the Harvey male line became extinct. Until the present time, there have been only a few portraits available of members of the Harvey family. In this paper, the author presents for the first time a unique collection of thirteen portraits (three by Sir Godfrey Kneller or his studio) of members of the Harvey family, spanning three centuries. Twelve are in the possession of the most senior remaining descendant of the Harvey family, and they may be referred to as the "Betchworth Portraits".

William Harvey's parents, Thomas and Joan Harvey of Folkestone, Kent, had a family of nine children - seven boys ("a week of sons" as Fuller puts it) and two girls. William Harvey (1578-1657), their first-born, left no progeny. His brother Daniel (1587-1649) had five sons and six daughters, but after a couple of generations, the male line died out, although the researches of the late Professor R. St. A. Heathcote traced the female line of this branch of the family down to the present time. ${ }^{1}$ However, from William Harvey's other brother, Eliab Harvey (1589-1661) of Rolls Park, Chigwell, Essex, the Harvey name continued to be handed on generation after generation for a couple of centuries, until with the death of Admiral Sir Eliab Harvey (1758-1830), the Harvey male line became extinct (see Table).

When the Admiral died, his three sons had already predeceased him, and he was survived by his six daughters. ${ }^{2}$ The Rolls Park estate passed to the eldest daughter, Louisa Harvey (1785-1866), who married William Lloyd of Aston Hall, Oswestry, Shropshire, while another daughter, Maria Harvey (1791-1875) married Reverend William Tower of Weald Hall, Essex. There are at the present time several families who can trace their descent directly from Louisa and Mary Harvey. The most senior remaining descendant now resides in Betchworth, Surrey.

Some portraits of the Harvey family have survived. The memorial tableau on the wall of the large dining room (later the rococo music room) of Rolls Park consisted of portraits (artist unknown, but possibly by Daniel Mytens (c. 1590-1648)) of Thomas Harvey, his seven sons (William, Thomas, John, Daniel, Eliab, Mathew, and Michael)

* Alex Sakula, M.D., F.R.C.P., D.H.M.S.A., Senior Phyșician, Redhill General Hospital, Surrey.

${ }^{1}$ Leonard M. Payne, 'The Harvey family of Folkestone and its descendants', Genealog. Mag. , 1957, 12: 345-346.

2 William J. Harvey, 'Genealogy of the family of Harvey compiled from original sources', Miscellanea Genealog. et. Herald, (2nd Series), 1888-89, 3: 329-336, 362-365, 381-384. 


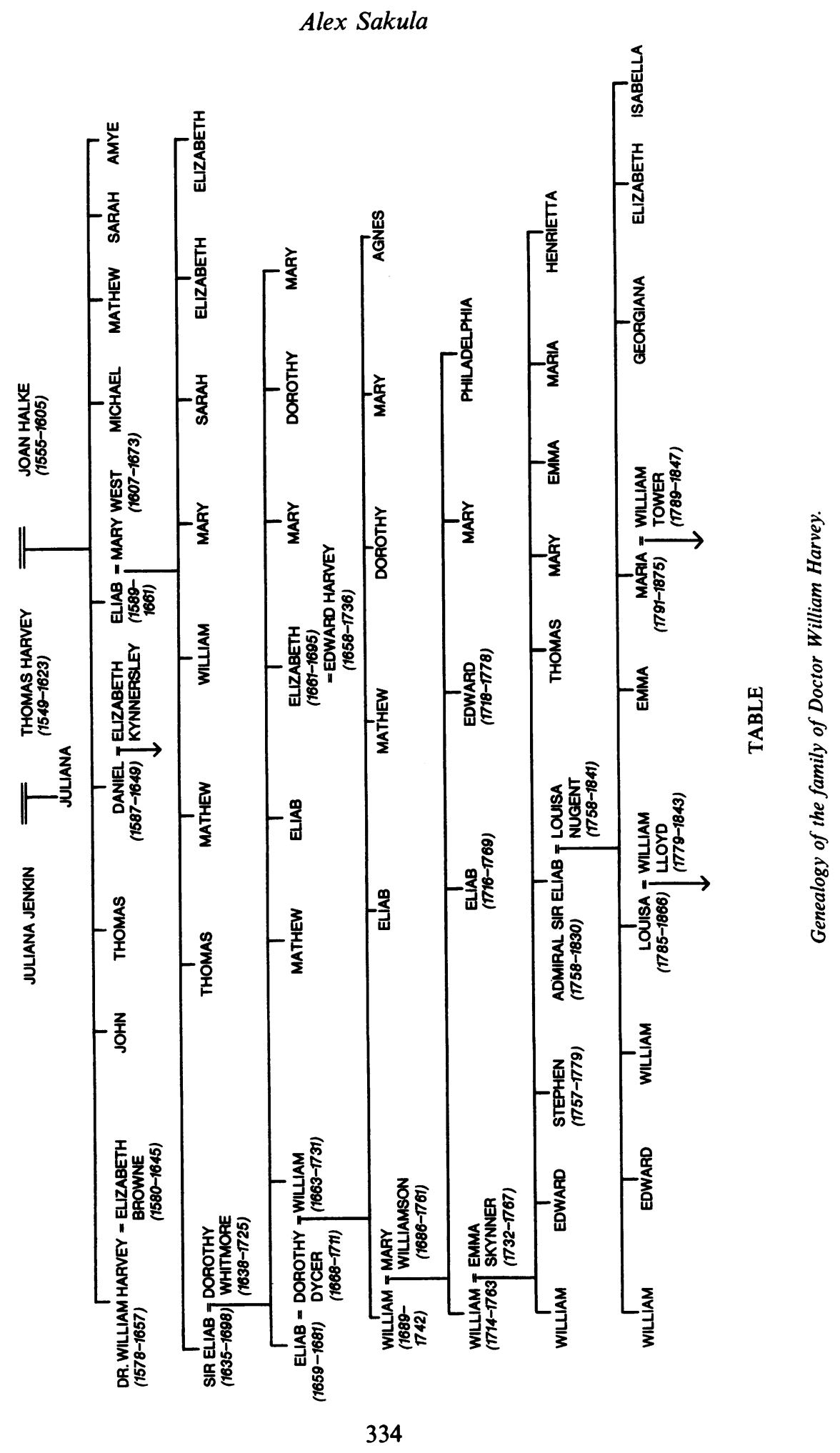


The Betchworth portraits: members of the family of William Harvey

and one of his daughters (possibly Amye). ${ }^{3}$ When they were rediscovered in 1948 by Sir Geoffrey Keynes, the portraits of Eliab and Mathew had been stolen, and the present whereabouts of these two are unknown. The remaining portraits of the tableau, which were the property of Mr. Andrew F. Lloyd, were removed for safe-keeping to the National Portrait Gallery, they were restored, and then hung for ten years in the Royal College of Physicians, London, following which they were returned to Mr. Lloyd. That of Doctor William Harvey was sold by Mr. Lloyd in 1959, and was exported illegally to a private purchaser in the United States, but it was returned to the National Portrait Gallery in 1977.4 There was another Rolls Park portrait, painted by William Dobson (1610-1646), which was considered by Sir D'Arcy Power ${ }^{5}$ as possibly that of William Harvey's brother, Eliab, and Sir Geoffrey Keynes included it as such in his 1948 Thomas Vicary Lecture. ${ }^{6}$ This portrait is now probably in private hands in the United States.

Another Rolls Park painting, by Sir Godfrey Kneller, was of a family group, consisting of a later William Harvey (1689-1742), his wife Mary Harvey (née Williamson) (1686-1761), their three sons: William (1714-1763), Eliab (1716-1769), and Edward (1718-1778), and also Mary Harvey's mother, Mrs. Williamson. This painting was recently sold by Mr. Andrew F. Lloyd and is at present on view at the Colnaghi Gallery, London. There is also a portrait of Sir Daniel Harvey (1631-1672) by Sir Peter Lely, now owned by Whitgift School, Croydon. In the Dundee Art Gallery there are portraits of the brothers William Harvey ${ }^{7}$ (1714-1763) and Edward Harvey (1718-1778), both by Allan Ramsay. Finally, there are portraits of Eliab Harvey's son, Sir Eliab Harvey (1635-1698) and his wife Lady Dorothy Harvey (née Whitmore) (1638-1725), from the collection of Sir Francis Whitmore of Orsett Hall, Romford. These two portraits were presented to the Harveian Society of London, which has loaned them to the Royal College of Physicians, London, where they are at present exhibited. ${ }^{8}$ No doubt there exist other Harvey family portraits which are in private possession.

It is because portraits of members of the family of William Harvey, especially of Eliab Harvey and his descendants, are relatively rare, that the recent discovery by the author of thirteen such portraits (including one of Doctor William Harvey) is considered to be of special medico-historical importance. They have chiefly been handed down within the families descended from Louisa Harvey and Maria Harvey, the major collection being at Betchworth, Surrey. These twelve Betchworth portraits (together with one from Doddershall, Buckinghamshire) form the subject of the present study. Reproductions of these portraits have not previously been published. 242.

${ }^{3}$ Sir D'Arcy Power, 'A memorial group of the Harvey family', Ann. med. Hist. , (new series), 1929, $1: 241$ -

4 William C. Gibson, 'Repatriation of the Rolls Park portrait of William Harvey', Bull. Hist. Med. , 1977, 51: 293-296.

5 Sir D'Arcy Power, Portraits of Dr. William Harvey, Oxford University Press, 1913, portrait V.

6 Sir Geoffrey Keynes, The portraiture of William Harvey, (Thomas Vicary Lecture, 1948), London, Royal College of Surgeons, 1949, Plate 31(b).

7 See Portrait VII.

8 Sir Gordon Wolstenholme and John F. Kerslake, The Royal College of Physicians of London. Portraits II, Amsterdam, Oxford, and New York, Excerpta Medica, 1977, pp. 128-131. 


\section{Alex Sakula}

\section{PORTRAIT I}

DOCTOR WILLIAM HARVEY (1578-1657)

Born 1 April 1578, first son of Thomas and Joan Harvey of Folkestone. Physician Extraordinary to James I, and Physician-in-Ordinary to Charles I. Physician to St. Bartholomew's Hospital. Lumleian Lecturer at Royal College of Physicians, London. Published in 1628 his famous work, De motu cordis, describing the circulation of the blood. Married Elizabeth, daughter of Dr. Lancelot Browne (Physician to Queen Elizabeth I). No progeny. Died at Roehampton 3 June 1657. Buried at Hempstead, Essex.

Artist: Unknown. A copy of a portrait attributed to CORNELIUS JANSSENS (also known as JANSSEN VAN KEULEN or as JOHNSON) (1593-1661).

Oils on canvas. $138 \mathrm{~cm} . \times 107 \mathrm{~cm}$. Unsigned.

Three-quarter length. Seated.

The original portrait was painted $c .1627$ (William Harvey was then aged c. 50). It was one of the two paintings rescued from the Royal College of Physicians at Amen Corner, in the Great Fire of London, 1666. It now hangs in the Harveian Library, Royal College of Physicians, London. Wolstenholme and Piper ${ }^{9}$ describe it as "by an artist unknown". D'Arcy Power" wrote: "There are several Janssen portraits of Harvey, some at least of which may have been painted as replicas by one or other of Janssen's pupils". The Betchworth portrait is unlikely to be such a replica and is probably an early nineteenth-century copy by an anonymous artist. It differs from that in the Royal College of Physicians in two details: (1) William Harvey's right hand rests on a red cloth, whereas in the Royal College of Physicians' portrait the hand rests on a stone parapet continuous with the pillar behind; and (2) there is no inscription GULIELMUS HARVEY, M.D. at the top of the picture.

Provenance: The painting was originally in Rolls Park. Following the death of Admiral Sir Eliab Harvey in 1830, it passed by descent to his daughter Maria Harvey (17911875), who married Reverend William Tower, and then to their daughter Louisa who in 1856 married Edward Goulburn (1816-1883) of Betchworth, Surrey.

\section{ELIAB HARVEY, ESQUIRE (1589-1661)}

\section{PORTRAIT II}

Brother of Doctor William Harvey.

Born 26 February 1589, fifth son of Thomas and Joan Harvey of Folkestone. Turkey merchant of Grocers' Company. Purchased Manor of Barrington, Chigwell, Essex, and built Rolls Park. Married Mary West 1624. Four sons and four daughters. Built Harvey mortuary chapel with burial vault below in Hempstead Church, Essex, 1655. Died 27 May 1661. Buried at Hempstead.

Artist: SIR PETER LELY (1618-1680) or his studio.

Oils on canvas. $122 \mathrm{~cm} . \times 97 \mathrm{~cm}$. Unsigned.

Three-quarter length. Probably painted after 1630 when the fashion for ruff gave way to plain collar. In lower right-hand corner there are three letters on a table, on one of which is written "To Mr. Eliab Harvey, MT. in London".

9 Sir Gordon Wolstenholme and David Piper, The Royal College of Physicians of London, Portraits I, London, Churchill, 1964, p. 204. 


\section{PORTRAIT I}

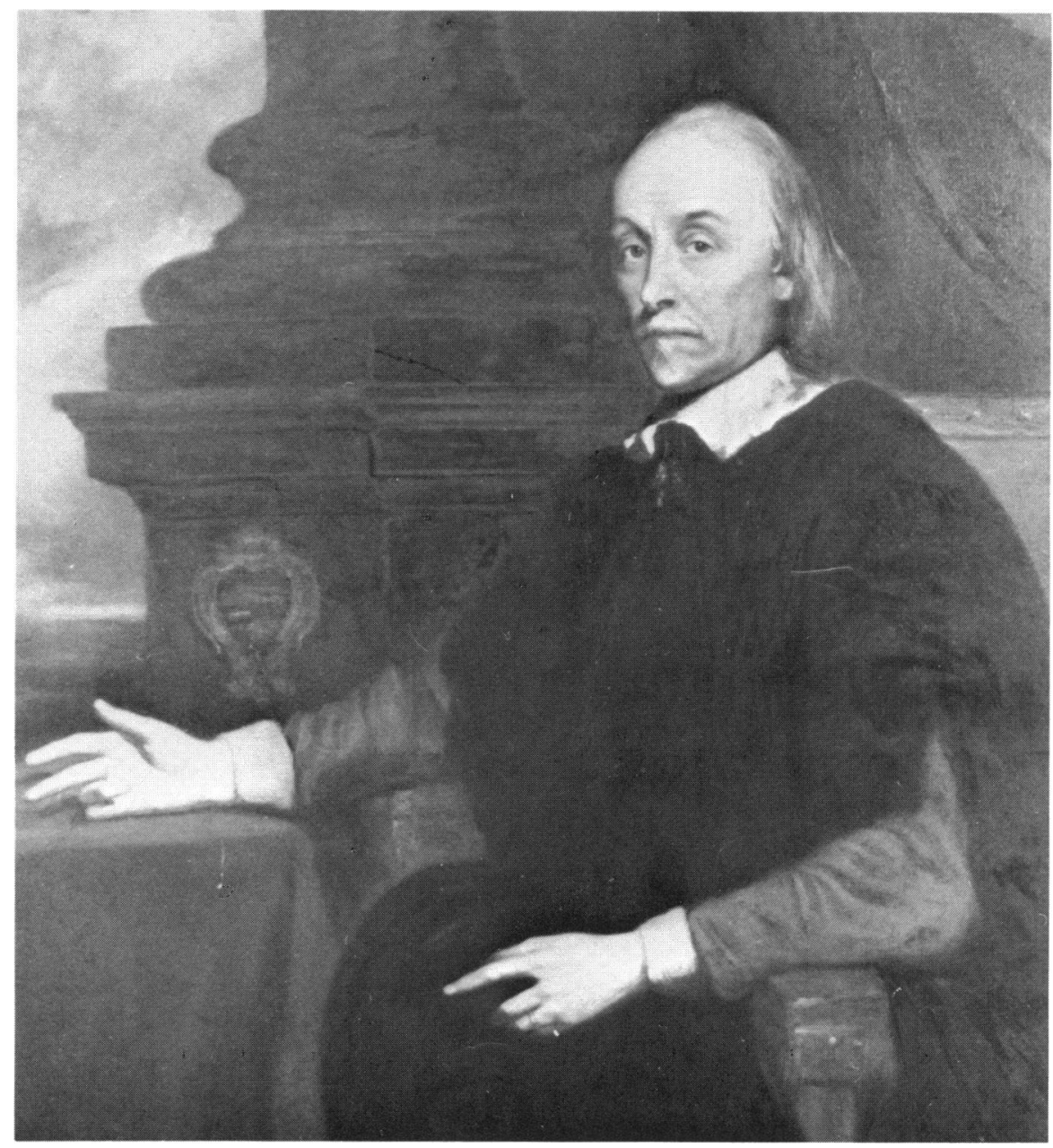

DR. WILLIAM HARVEY

1578-1657

attributed to Cornelius Janssens 


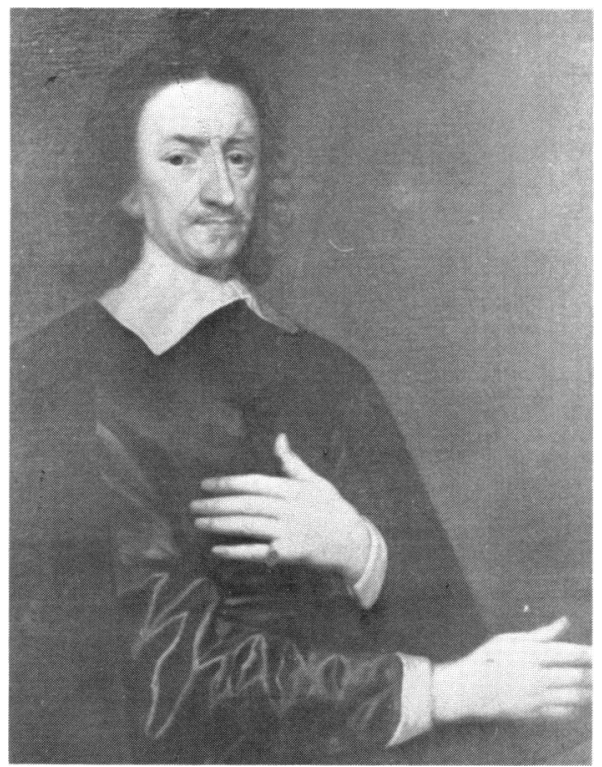

ELIAB HARVEY, ESQ.

1589-1661

by Sir Peter Lely or his studio

PORTRAIT III

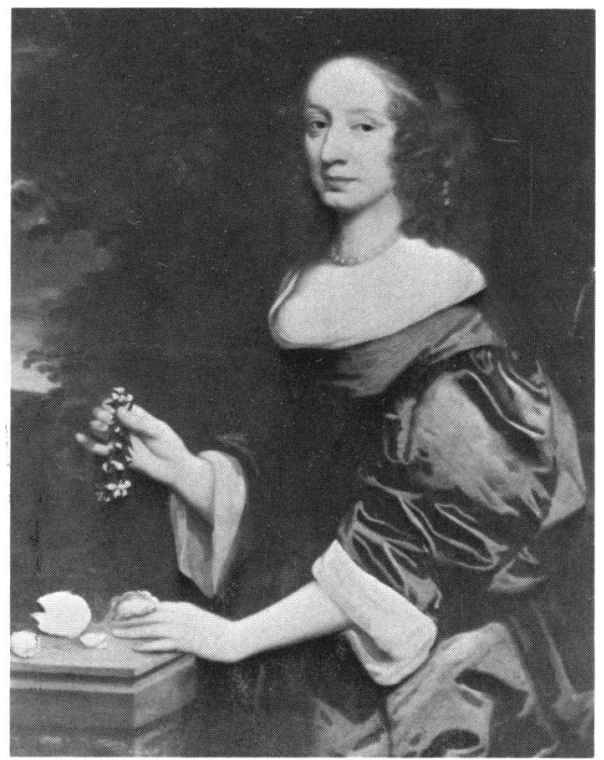

MARY HARVEY

1607-1673

by Gerard Soest 


\section{PORTRAIT IV}

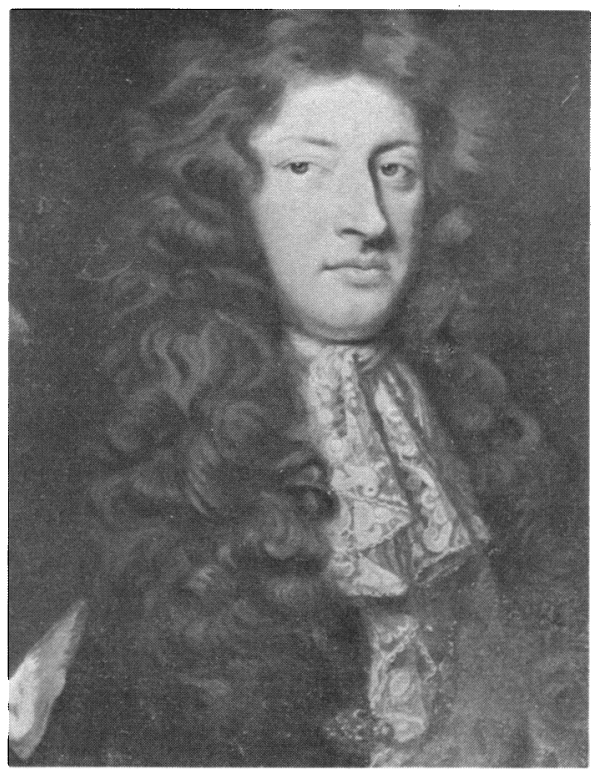

EDWARD HARVEY, ESQ. MP.

$1658-1736$

by Sir Godfrey Kneller or his studio

\section{PORTRAIT V}

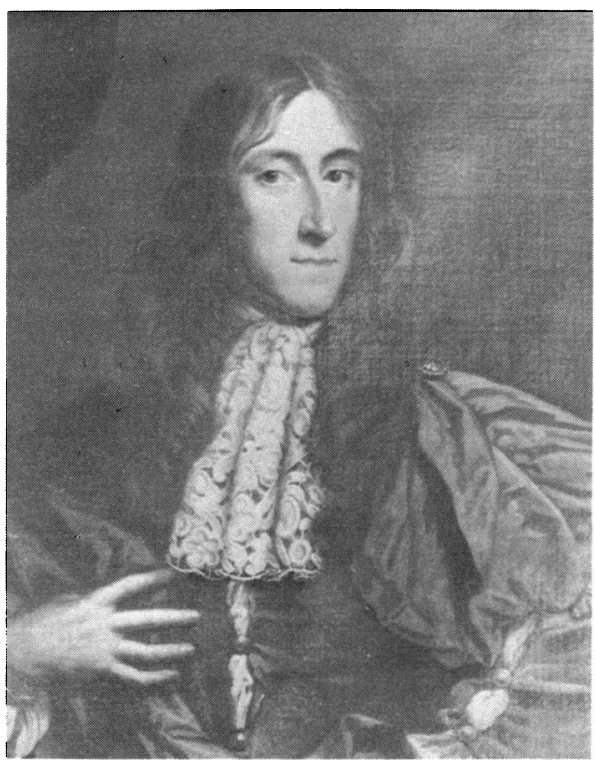

WILLIAM HARVEY, ESQ. MP. 1663-173

by Sir Godfrey Kneller or his studio
PORTRAIT VI

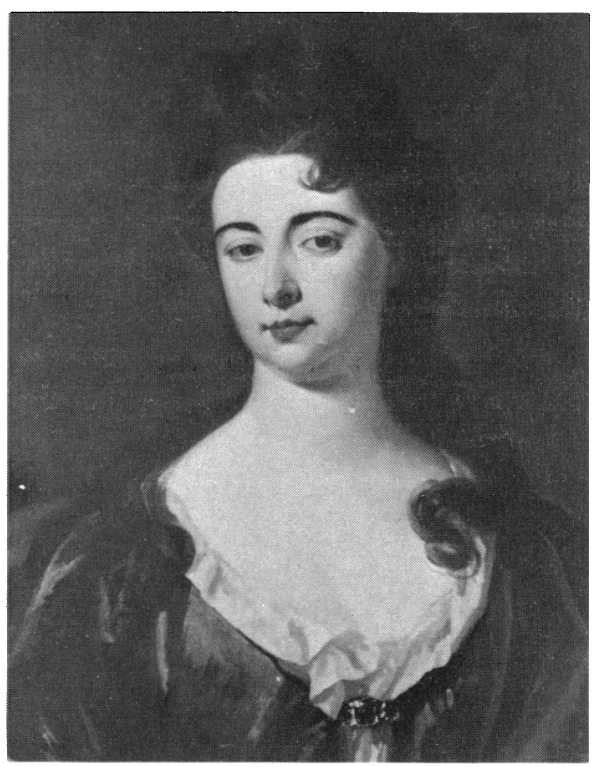

DOROTHY HARVEY

1668-1711

by Sir Godfrey Kneller or his studio 


\section{PORTRAIT VII}

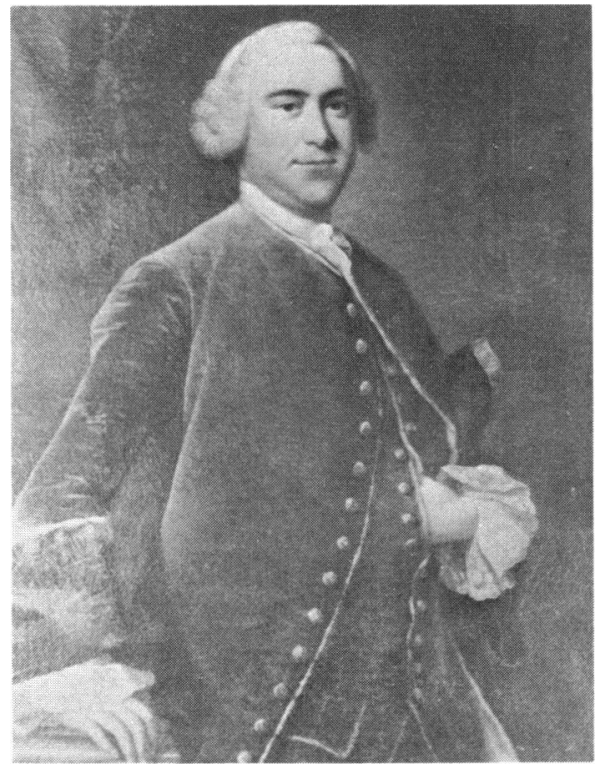

WILLIAM HARVEY, ESQ. MP.

1714-1763

by Thomas Hudson

\section{PORTRAIT VIII}

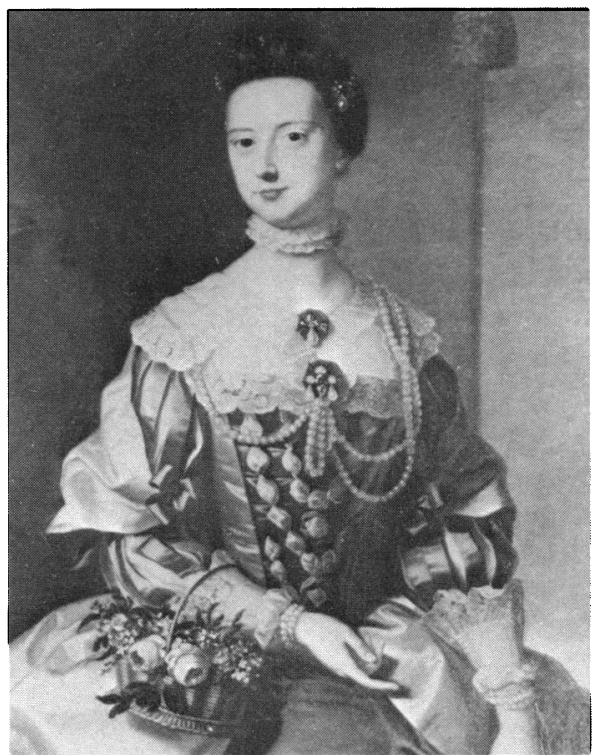

EMMA HARVEY

1732-1767

by Thomas Hudson 
PORTRAIT IX

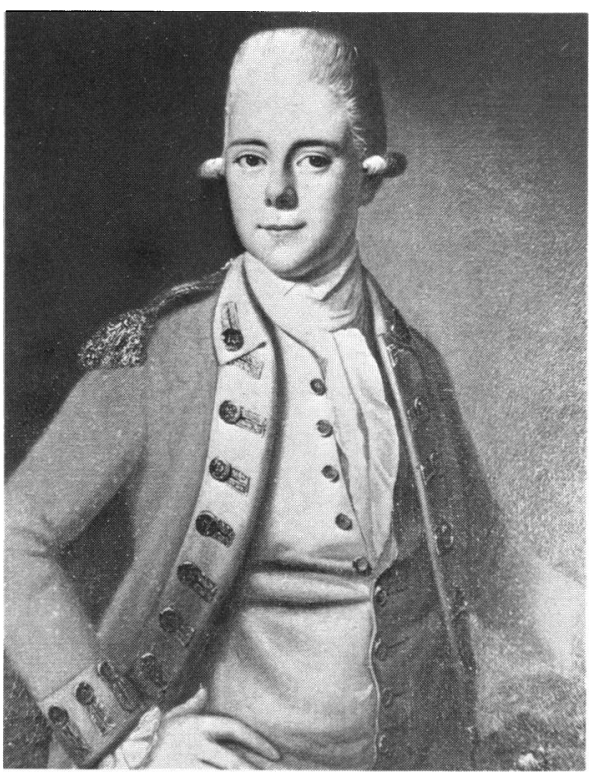

LIEUTENANT STEPHEN HARVEY

1757-1779

Artist Unknown

\section{PORTRAIT X}

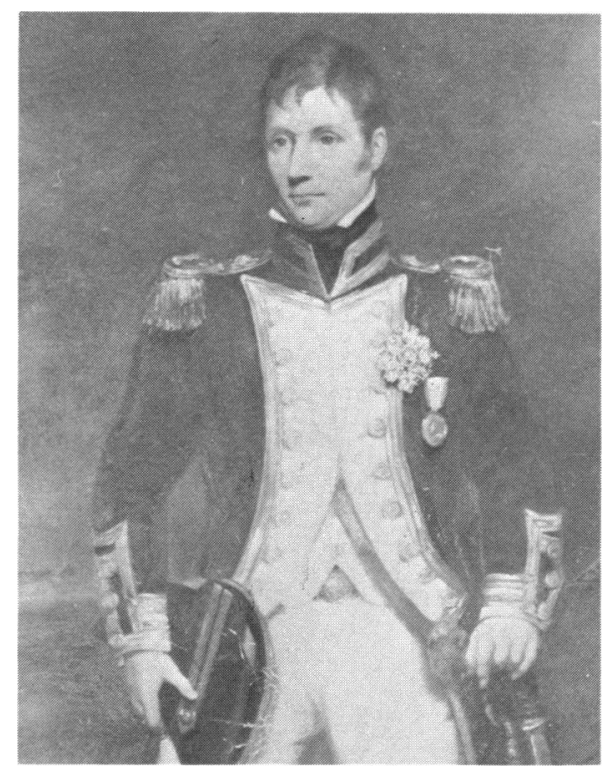

ADMIRAL SIR ELIAB HARVEY

1758-1830

Attributed to Lemuel Frances Abbot 
PORTRAIT XII

PORTRAIT XI
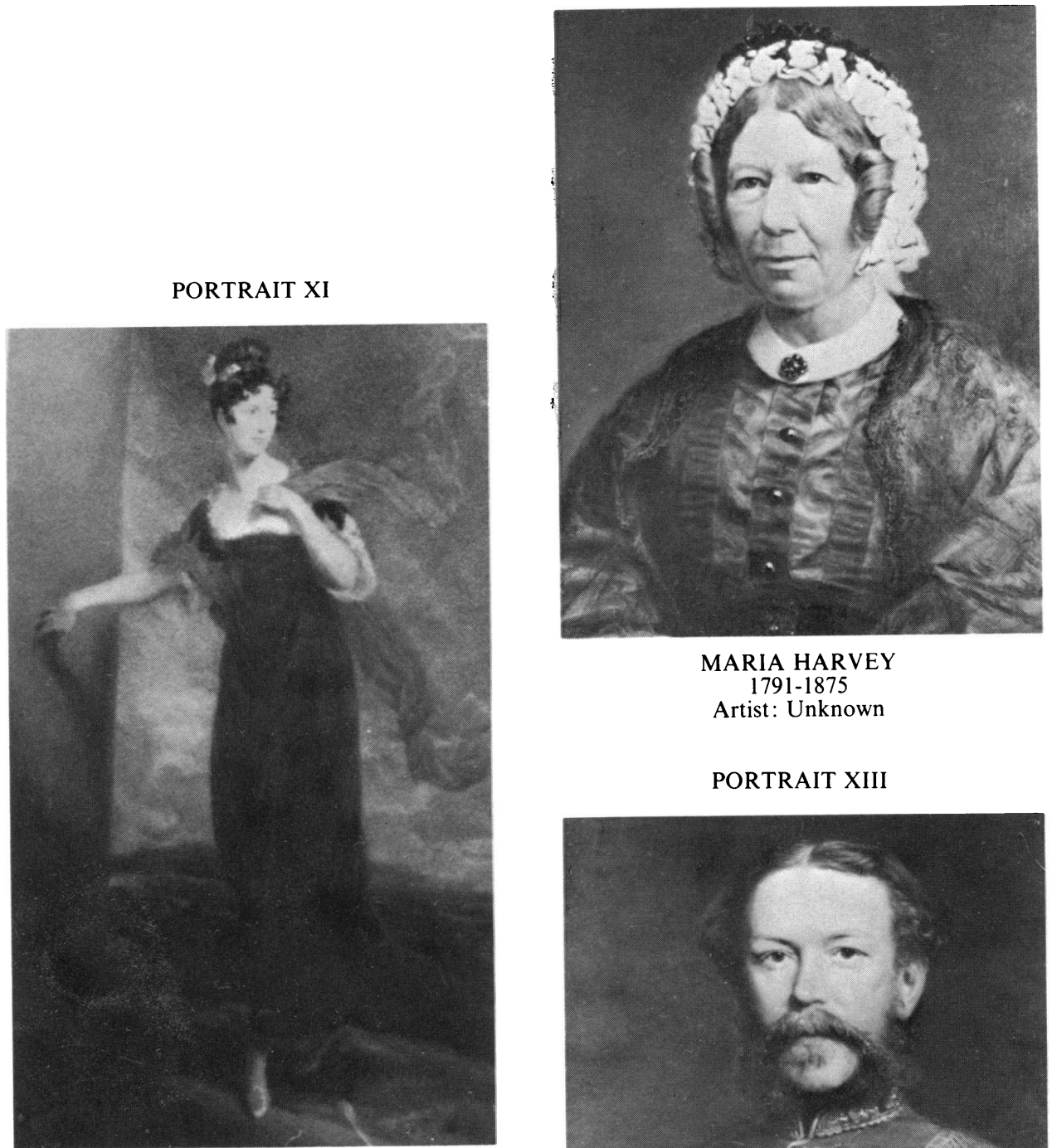

MARIA HARVEY

1791-1875

Artist: Unknown

PORTRAIT XIII

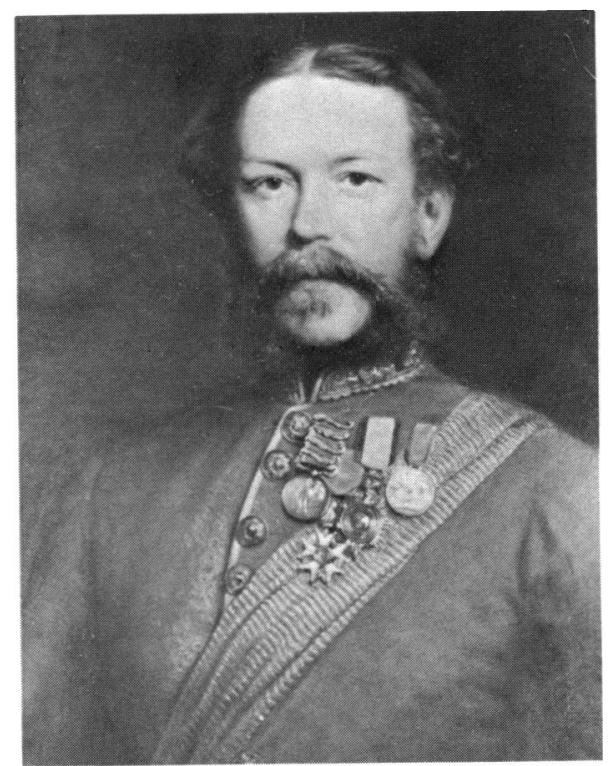

CAPTAIN HARVEY TOWER

1831-1870

by James Godsell Middleton 


\section{The Betchworth portraits: members of the family of William Harvey}

Provenance: The painting was originally in Rolls Park. It was sold at Christie's in 1953. Sale catalogue description: "The property of Andrew F. Lloyd, Esq., and came originally from Rolls Park, Chigwell, Essex. Lot 45: Portrait of Eliab Harvey Esq., in a brown cloak, standing by a table. - Lely." The purchaser was the National Portrait Gallery, who retained the original frame and resold the canvas to Major-General Edward Henry Goulburn, D.S.O., of Betchworth, Surrey.

MARY HARVEY (1607-1673)

\section{PORTRAIT III}

Wife of Eliab Harvey, Esquire (1589-1661).

Born in London in 1607, daughter of Francis West, gentleman. Married at St. Laurence Pountenay, 15 February 1624. Four sons and four daughters. Died 30 December 1673. Buried at Hempstead, Essex.

Artist: GERARD SOEST (1637-1681).

Oils on canvas. $127 \mathrm{~cm} . \times 97 \mathrm{~cm}$. Unsigned.

Three-quarter length.

Provenance: The painting was originally in Rolls Park. It was sold at Christie's in 1953. Sale catalogue description: "The property of Andrew F. Lloyd, Esq., and came originally from Rolls Park, Chigwell, Essex. Lot 45: Portrait of Mary Harvey, age 45, in a mauve dress, holding some flowers. - Lely." Later, because of its style and colouring, attributed to Gerard Soest. The purchaser was the National Portrait Gallery, who retained the original frame and resold the canvas to Major-General Edward Henry Goulburn, D.S.O., of Betchworth, Surrey.

\section{PORTRAIT IV}

EDWARD HARVEY, ESQUIRE, M.P. (1658-1736).

Grandson of Daniel Harvey (1587-1649), a brother of Doctor William Harvey.

Born 30 March 1658, son of Sir Daniel Harvey (1631-1672). His mother was Elizabeth, daughter of Lord Montague. Lived at Combe Nevel. High Steward of Kingston-upon-Thames. Member of Parliament 1678-1715. Married (1) his cousin Elizabeth Harvey (1661-1695), daughter of Sir Eliab Harvey, in 1679; (2) Elizabeth, daughter of Earl of Bradford, in 1702; and (3) Mary Carteret, in 1725. Died at Dunkirk on 24 October 1736. Buried at Hempstead, Essex.

Artist: SIR GODFREY KNELLER (1646-1723) or his studio.

Oils on canvas. $128 \mathrm{~cm} . \times 99 \mathrm{~cm}$. Unsigned.

Three-quarter length.

Provenance: The painting was originally in Rolls Park. It was sold at Christie's in 1953. Sale catalogue description: "The property of Andrew F. Lloyd Esq., and came from Aston Hall, Oswestry, Shropshire. Lot 39: Portrait of Edward Harvey Esq., age 25, in a brown coat with lace cravat and red cloak. - Kneller." The purchaser was the National Portrait Gallery, who retained the original frame and resold the canvas to Major-General Edward Henry Goulburn, D.S.O., of Betchworth, Surrey. 


\section{Alex Sakula}

\section{PORTRAIT V}

WILLIAM HARVEY, ESQUIRE, M.P. (1663-1731)

Grandson of Eliab Harvey (1589-1661), a brother of Doctor William Harvey.

Born December 1663, son of Sir Eliab Harvey (1635-1698). Mother was Lady Dorothy Harvey (née Whitmore) (1638-1725). Member of Parliament 1689-1722. Married Dorothy Dycer 1681. Three sons and three daughters. Died 31 October 1731. Buried at Hempstead, Essex.

Artist: SIR GODFREY KNELLER (1646-1723) or his studio.

Oils on canvas. $128 \mathrm{~cm} . \times 99 \mathrm{~cm}$. Unsigned.

Three-quarter length. Wearing full brown wig.

Provenance: The painting was originally in Rolls Park. It was sold at Christie's in 1953. Sale catalogue description: "The property of Andrew F. Lloyd, Esq., and came originally from Aston Hall, Oswestry, Shropshire. Lot 39: Portrait of a Gentleman in classical dress in red scarf. - Kneller." The purchaser was the National Portrait Gallery, who retained the original frame and resold the canvas to Major-General Edward Henry Goulburn, D.S.O., of Betchworth, Surrey.

\section{PORTRAIT VI}

DOROTHY HARVEY (1668-1711).

Wife of William Harvey Esq., M.P. (1663-1731).

Born May 1668, daughter of Sir Robert Dycer, Bart., of Uphall, Braughing, Hertfordshire. Her mother was Judith, daughter of Richard Gulston of Widdial, Hertfordshire. Married twice, two of Sir Eliab Harvey's sons: (1) Eliab Harvey (16591681); and (2) William Harvey (1663-1731). Three sons and three daughters. Died 28 June 1711. Buried at Hempstead, Essex.

Artist: SIR GODFREY KNELLER (1646-1723) or his studio.

Oils on canvas. $72 \mathrm{~cm} . \times 60 \mathrm{~cm}$. Unsigned.

Head and shoulders. Low-neck blue dress, with red scarf.

Provenance: The painting was originally in Rolls Park. Following the death of Admiral Sir Eliab Harvey in 1830, it passed by descent to his daughter Maria Harvey (17911875), who married Reverend William Tower, and then to their daughter Louisa who in 1856 married Edward Goulburn (1816-1887), grandfather of Major-General Edward Henry Goulburn, D.S.O., of Betchworth, Surrey.

\section{PORTRAIT VII}

WILLIAM HARVEY, ESQUIRE, M.P. (1714-1763).

Great-great-grandson of Eliab Harvey (1589-1661), a brother of Doctor William Harvey. Father of Admiral Sir Eliab Harvey (1758-1830) and Lieutenant Stephen Harvey (1757-1779).

Born 9 June 1714. Colonel of Western Battalion, Essex Militia. Member of Parliament for Essex 1747-1761. Married Emma Skynner 1750. Five sons and four daughters. Died 11 June 1763. Buried at Hempstead, Essex.

Artist: THOMAS HUDSON (1701-1779).

Oils on canvas. $127 \mathrm{~cm} . \times 97 \mathrm{~cm}$. 
The Betchworth portraits: members of the family of William Harvey

Three-quarter length. Blue suit. Wearing short blond wig. 10

Provenance: The painting was originally in Rolls Park. Following the death of Admiral Sir Eliab Harvey in 1830, it passed by descent to his daughter Maria Harvey (17911875), who married Reverend William Tower, and then to their daughter Louisa who in 1856 married Edward Goulburn (1816-1887), grandfather of Major-General Edward Henry Goulburn, D.S.O., of Betchworth, Surrey.

EMMA HARVEY (1732-1767).

\section{PORTRAIT VIII}

Wife of William Harvey, Esq., M.P. (1714-1763). Mother of Admiral Sir Eliab Harvey (1758-1830).

Born 1732, daughter of Stephen Skynner of Walthamstow, Essex. Her mother was Mary, daughter of Samuel Remington of Low Leyton, Essex. Married William Harvey 1750. Five sons and four daughters. Died 14 March 1767. Buried at Hempstead, Essex. Artist: THOMAS HUDSON (1707-1779).

Oils on canvas. $127 \mathrm{~cm} . \times 97 \mathrm{~cm}$.

Three-quarter length. Ornate blue and white silk dress, decorated with pearls. Holding basket of flowers.

Provenance: The painting was originally in Rolls Park. Following the death of Admiral Sir Eliab Harvey in 1830, the painting passed by descent to his daughter Maria Harvey (1791-1875), who married Reverend William Tower, and then to their daughter Louisa who in 1856 married Edward Goulburn (1816-1887), grandfather of Major-General Edward Henry Goulburn, D.S.O. of Betchworth, Surrey.

Another portrait, also by Thomas Hudson, virtually identical except for the arrangement of the pearls, was formerly in the collection of G. Wilbraham, and was exhibited at the British Exhibition in 1934 at Burlington House (No. 238); it was sold by Sotheby's to Agnew's in 1958.

\section{PORTRAIT IX}

LIEUTENANT STEPHEN HARVEY (1757-1779).

Brother of Admiral Sir Eliab Harvey.

Born 1757. Son of William Harvey (1714-1763) of Rolls Park. Mother was Emma Harvey (née Skynner). Lieutenant H.M. 2nd Regiment of Foot. Unmarried. Killed 1779 at Saratoga, North America, and buried there.

Artist: Unknown.

Oils on canvas. $85 \mathrm{~cm} . \times 70 \mathrm{~cm}$.

Three-quarter length. Standing. Army lieutenant's uniform with sword. Wearing short grey wig.

Provenance: This painting passed by descent to Maria Harvey's daughter, Louisa, who in 1856 married Edward Goulburn (1816-1887), grandfather of Major-General Edward Henry Goulburn, D.S.O. of Betchworth, Surrey.

10 There is another portait, by Allan Ramsay (1713-1784), in the Dundee Art Gallery. 


\section{Alex Sakula}

PORTRAIT X

ADMIRAL SIR ELIAB HARVEY, G.C.B., M.P. (1758-1830).

Great-great-great grandson of Eliab Harvey (1589-1661), who was a brother of Doctor William Harvey.

Born 5 December 1758. Son of William Harvey (1714-1763) of Rolls Park. Mother was Emma Harvey (née Skynner). Admiral of the Blue. Distinguished action in the Téméraire at Trafalgar 1805. ${ }^{11}$ Member of Parliament for Maldon and later for Essex 1780-1826. K.C.B. 1815, G.C.B. 1825. Married Louisa, daughter of Robert, Earl Nugent, 1784. Three sons and six daughters. Died 20 February 1830. Buried at Hempstead, Essex. With his demise, the Harvey male line became extinct.

Artist: attributed to LEMUEL FRANCES ABBOT (1760-1803).

Oils on canvas. $140 \mathrm{~cm} . \times 108 \mathrm{~cm}$. Unsigned.

Almost full length. Standing. Full naval captain's uniform. Holding hat. Decorations: Captain's Trafalgar gold medal; Star of Order of Bath; Red sash of Order of Bath.

Since Abbot died 1803, this portrait may be a copy of an earlier one, with the decorations added.

Provenance: The painting was originally in Rolls Park. Following his death in 1830 , it passed by descent to his daughter Maria Harvey (1791-1875), who married Reverend William Tower, and then to their daughter Louisa who in 1856 married Edward Goulburn, grandfather of Major-General Edward Henry Goulburn, D.S.O., of Betchworth, Surrey.

\section{LOUISA HARVEY (1785-1866).}

\section{PORTRAIT XI}

Daughter of Admiral Sir Eliab Harvey (1758-1830).

Born in St. Marylebone 1785. Married 8 October 1804 to William Lloyd (1799-1843) of Aston Hall, Oswestry, Shropshire. Four sons and two daughters. Died at Aston Hall, 7 March 1866.

Artist: SIR GEORGE HAYTER (1792-1871).

Oils on canvas. $200 \mathrm{~cm} . \times 110 \mathrm{~cm}$.

Painted $c$. 1825, when she was aged forty.

Full length. Standing. Dark blue dress. Flowing red scarf.

Provenance: This painting was originally in Aston Hall, and has passed by descent in the Lloyd and Pigott families to Louisa Harvey's great-great-great-grandson, Christopher Lloyd Prideaux of Doddershall, Buckinghamshire.

\section{MARIA HARVEY (1791-1875).}

\section{PORTRAIT XII}

Daughter of Admiral Sir Eliab Harvey (1758-1830).

Born at Rolls Park 6 April 1791. Married 13 June 1825 to Reverend William Tower (1789-1847) of Weald Hall, Essex. One son and three daughters. Died 1875. Artist: Unknown.

11. Alex Sakula, 'Admiral Sir Eliab Harvey of the Téméraire: a distinguished kinsman of William Harvey', J. $R$ nav. med. Serv., 1979, 65: 153-164. 
The Betchworth portraits: members of the family of William Harvey

Oils on canvas. $73 \mathrm{~cm} . \times 60 \mathrm{~cm}$.

Half length. Seated. Plain blue dress buttoned to neck. Lace bonnet. Sitter was then widow, aged $c$. sixty.

Provenance: This painting passed by descent to Maria Harvey's daughter, Louisa, who in 1856 married Edward Goulburn (1816-1887), grandfather of Major-General Edward Henry Goulburn, D.S.O., of Betchworth, Surrey.

\section{PORTAIT XIII}

CAPTAIN HARVEY TOWER (1831-1870)

Son of Maria Harvey (1791-1875), a daughter of Admiral Sir Eliab Harvey (17581830).

Captain, Coldstream Guards.

Died unmarried.

Artist: JAMES GODSELL MIDDLETON (fl. 1826-1872).

Oils on canvas. $71 \mathrm{~cm} . \times 60 \mathrm{~cm}$.

Half-length. Red army-officer's uniform.

Provenance: This painting passed by descent to Maria Harvey's daughter, Louisa, who married Edward Goulburn (1816-1887), grandfather of Major-General Edward Henry Goulburn, D.S.O., of Betchworth, Surrey.

\section{ACKNOWLEDGMENTS}

I wish to express my thanks to Major-General Edward Henry Goulburn, D.S.O., and to Lady Joan Prideaux for their willing co-operation and permission to publish these Harvey family portraits. Unfortunately while this article was in press, Major-General Edward Henry Goulbourn died on 15 February 1980. 